\title{
シュウ酸および硝酸溶液中のアルミニウムの 定電位における電流一時間曲線についで
}

\author{
佐藤栄 一* \\ Anode Current-Time Curves of Aluminum in Oxalic and Nitric \\ Acid under Controlled Potential Electrolysis \\ Studies on Aluminum Anode for Cathodic Protection (Part 1)
}

Eiichi SATO

The formation of oxide film on aluminum in oxalic and nitric acid was investigated by means of an apparatus consisting of a potentiostat and a high sensitive recorder.

The results obtained were summarized as follows :

1) In oxalic acid

(a) When the set potential was maintained at $2 \mathrm{~V}$ in oxalic acid, straight lines having constant slopes were obtained during the period of electrolysis up to $6 \mathrm{sec}$., which represented the formation of oxide films by ionic conduction. After the lapse of more than $6 \mathrm{sec}$., the film was not changed to an insulating one; however, after $4 \mathrm{~min}$., the anode current began to be decreased and the compact film began to be formed again.

(b) When the potential was set at $1 \mathrm{~V}$, two straight lines having different slopes appeared at 6 sec. of electrolysis. The film formed would be a complicated one, consisting of an ionic conduction film and an insulating film.

(c) When the potential was set at $0.7 \sim-0.3 \mathrm{~V}$, each of the curves appeared in a similar type. That it; the ionic conduction film at the earlier stage of electrolysis was converted into an insulating film very soon.

(d) A1 P3 represented curves similar to that of the known high purity aluminum. Therefore, it would proceed in the same electrochemical process.

2) In nitric acid

(a) When the set potential was maintained at $2 \mathrm{~V}$ in nitric acid, the anode current was rapidly increased with the lapse of time after the electrolysis of $1 \mathrm{sec}$.

(b) When the set potential was maintained at $1 \mathrm{~V}$, the formation of film by ionic conduction was continued during the period of electrolysis up to $90 \mathrm{sec}$., because the relation between $\log \mathrm{I}$ and $\log \mathrm{T}(\mathrm{T}=\sqrt{1+58.72 t})$ was expressed by a straight line in this period. The anode current was increased with the lapse of time which showed that the dissolution of the oxide film occurred.

(c) When the set potential was maintained at $0 \sim-0.3 \mathrm{~V}$, each of the curves appeared in a similar type, which was nearly the same as the result in 1) (c).

(d) A1 P3 represented the same current-time curves as those in 1) (d) so that the same electrochemical process of film formation would proceed.

$†$ 流電陽極用アルミニウム合金に関する研究（第 1 報）

* 神奈川県工業試験所（神奈川県横浜市金沢区富岡町 3,173）

Industrial Research Institute of Kanagawa Prefecture 


\section{1. 緒吾}

アルミニウムの用途は激増の一途をたどり，近年は原 子炉材や電気防食用アノード, 電池用アノードとしての 特殊な応用面にも進出している。このような増加は, ア ルミニウムの耐食性が必らずしも十分でないにもかかわ らず，アルマイト加工をはじめ，アルミニウムの表面処 理技術の進歩に負らところが非常に大きいものと思われ る。

さて技術的諸要素から考えるならば，実用金属材料と してのアルミニウムに関する限り，経験的諸技術は一応 完結したかのように考学られるが，アルミニウムの表面 処理方法一つをとっても，応用研究を急がれるあまり試 行錯誤的な開発研究に力を注ぎ，今日まで至った形跡が らかがわれる。

もちろん，一方に执いては，工業技術が確立されたも のについては現在かなり多くの基礎研究がなされてい る。

しかし最近開発された防食用アノードなどについて は，清浄海水中は別として，污染海水中では局部腐食が 発生進行するなぞ，これらの腐食現象に対する基礎的知 見はまったくないといえる。

ここでは一応，シュウ酸扣よび硝酸の $\mathrm{pH} 1$ の溶液を とりあげ，ポテンシオスタットを用いて，各電位に設定 し，そのとき流れる電流の経時变化を記録し，酸化皮膜 の生成機構などについて検討したので報告する。

\section{2. 実験}

\section{2-1 試料および試菜}

試験片には純度 $99.999 \%$ で厚サ $1 \mathrm{~mm}$, 幅 $15 \mathrm{~mm}$ の 板と, 同形の市販の A 1 P 3 板を使用した。A 1 P 3 の 化学組成は第 1 表に示したと拈りである。

実際に使用した表面積は，10×10 $\mathrm{mm}^{2}$ になるように パラフィンで鋈布した。表面処理方法は加藤りによって 報告された最適表面処理方法に準拠した。実際に用いた 方法は次のようなるのである。 $2 / 0$ エメリー紙で研摩 水洗 $\rightarrow 10 \mathrm{~N} \mathrm{NaOH}$ 飞浸七キ(液温 $50^{\circ} \mathrm{C}$, 浸七キ時間 30 $\mathrm{s}$ ) $\rightarrow$ 水洗 $\rightarrow 10 \% \mathrm{HNO}_{3}$ (室温, 浸七キ時間 $30 \mathrm{~s}$ ) $\rightarrow 1 \mathrm{~N}$

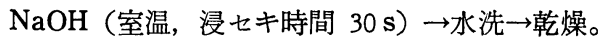

酸化皮膜が直接実験結果に影響するので，できるだけ 酸化皮膜を除去するように努めた。

実験に用いた試薬は，すべて市眅の特級品をそのまま

第 1 表 A1 P3 の化学組成 (\%)

\begin{tabular}{l|c|c|c|c|c|c|c|c}
\hline & $\mathrm{Cu}$ & $\mathrm{Si}$ & $\mathrm{Fe}$ & $\mathrm{Mn}$ & $\mathrm{Mg}$ & $\mathrm{Zn}$ & $\mathrm{Ti}$ & $\mathrm{Al}$ \\
\hline A1P3 & 0.00 & 0.09 & 0.30 & 0.00 & 0.00 & 0.01 & 0.03 & $\mathrm{Bal}$ \\
\hline \hline
\end{tabular}

使用した。

$\mathrm{pH}$ の調節には，東亜電波製 $\mathrm{pH}$ メーターを使用して 正確に 1 とした。

\section{2一2 装宣および測定方法}

電解ソウは硬質ガラス製で容積 $300 \mathrm{~m} l$ のもので側面 に $10 \times 10 \mathrm{~mm}^{2}$ の面積をるった白金板が取り付けてあ る。

定電位にはポテンシオスタット(日业計器製 EH-P型) を用い, 電流の記録には電流変換器と, ダイヤル形可変 抵抗器と横河電機製の高感度記録計を使用した。照合電 極には, 東亚電波製の飽和甘ュウ電極 (以後 S C E と省 略する）を用いた。照合電極から電解ソウ溶液中への塩 素イオンの混入防止には中間液を設け，かつ S C Eから 中間液へ塩素イオンの流入をさけるため寒天橋を使用し た。使用した水は 1 回蒸留した蒸留水である。

試験液から酸素を除去するためには, 硫酸チタン一亜 鉛アマルガム混合溶液とアルカリーピロガロール混合溶 液を通した高純度窒素ガスを電解液にあらかじめ 30 min 以上吹さ込んだ。

測定中も電解液は窒素ふんい気である。

\section{3. 実験結果および考察}

\section{3-1 シュウ酸溶液中のアルミニウムの電流一時間曲 線について}

高純度アルミニウム電極の電位を, 酸素発生電位より 貴と早の両電位領域の $2 \mathrm{~V}, 1 \mathrm{~V}, 0.7 \mathrm{~V}, 0 \mathrm{~V}$ と一 0.3 $\mathrm{V}$ の一定に設定した場合の実験結果の一例を，第 1 図と

\section{第 2 図に示す。}

電極面に生成する皮膜の電気的性質と，その電気化学 的性質はすこぶる重要な関係があるから，溶液と酸化皮 膜との間の界面物性の研究には電気的手法が用いられ，

数多くの研究が報告されている。

Schottky や Franck などもそれらの研究者であり, いま Franck ${ }^{2}$ とよれば,生成皮膜がイオン電導性の場合 と絶縁皮膜との場合には，定電位条件下での電流一時間 曲線は次に示すような式に従って変化するとしている。

すなわちイオン電導性皮膜が形成される場合には,

$$
\begin{aligned}
& \frac{d \delta}{d t}=K d\left(I-I_{\kappa}\right) \\
& E=E a+\rho \delta I \ldots \ldots \ldots
\end{aligned}
$$

ここで,

$\delta:$ 皮膜の厚サ $K d:$ 定数

$I_{k}$ : 皮膜の溶解に対する補正項 $E$ : 電位

$E a: \delta$ (皮覆度) $=1$ 亿なったときの電位

$\rho:$ 皮膜の比抵抗

(2)式より 


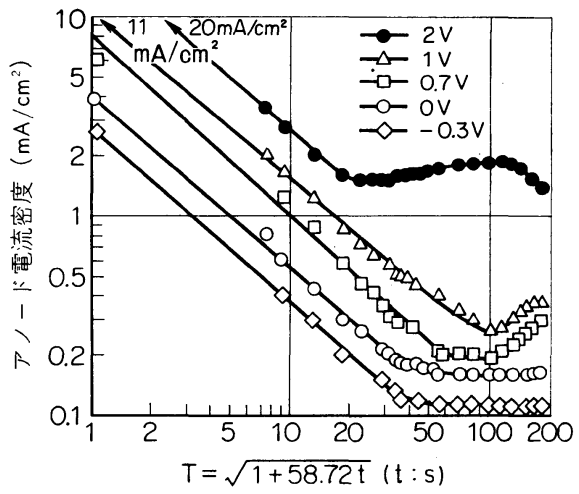

第1図定電位条件下でのシュウ酸溶液中のア ルミニウムのアノード電流と時間の各 対数との関係

$$
I=\frac{E-E a}{\rho \delta}
$$

(1)式より $I_{k} \ll 1$ とすれば

$$
d \delta=K d I d t
$$

(3)式を代入すると

$$
\begin{aligned}
& d \delta=K_{d} \frac{E-E a}{\rho \delta} d t \\
& E, \quad E a: \text { 一定にすると } \\
& \delta d \delta=\frac{K_{d}}{\rho}(E-E a) d t \\
& 1 / 2 \delta^{2}=\frac{K_{d}}{\rho}(E-E a) t+C \\
& \delta=\sqrt{\frac{2 K d}{\rho}(E-E a) t+2 C}
\end{aligned}
$$

(3)式代代入すると

$$
I=\frac{E-E a}{\sqrt{2 K_{a} \rho(E-E a) t+A}}
$$$$
\text { ここで, } A \text { は積分定数 }
$$$$
t=0 \text { のとき, } I=I a \text { であるから }
$$$$
I a=\frac{E-E a}{\sqrt{A}}
$$$$
\therefore A=\left(\frac{E-E a}{I a}\right)^{2}
$$$$
\therefore I=\frac{E-E a}{\sqrt{2 K_{d} \rho(E-E a) t+\left(\frac{E-E a}{I a}\right)^{2}}}
$$

$$
=\frac{I a}{\sqrt{\frac{2 K_{d} \rho I a^{2}}{E-E a} t+1}}
$$

$$
\begin{gathered}
K s=\frac{2{ }_{a} K \rho I a^{2}}{E-E a} \\
I=\frac{I a}{\sqrt{1+K s t}}
\end{gathered}
$$

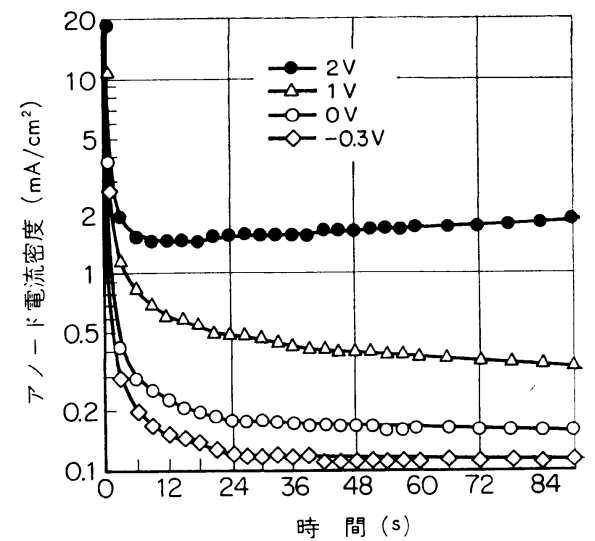

第 2 図定電位条件下でのシュウ酸溶液中のア ルミニウムのアノード電流の対数と時 間の関係

ゆえに電流 $I$ の対数と, 時間 $T=\sqrt{1+58.72 t}$ の対 数の関係は直線関係となる。

さて，絶縁皮膜が形成される場合には，

$$
\begin{aligned}
& I_{g}=I_{w}(1-\alpha) \\
& \frac{d \delta}{d t}=K_{b}\left[I_{w}(1-\alpha)-I_{k}\right]
\end{aligned}
$$

(5)式を変形すると

$$
\frac{d \delta}{d t}+K_{b} I_{w} \alpha=K_{b}\left(I_{w}-I_{k}\right)
$$

ここで, $I_{g}:$ 見かけの電流密度, $I_{w}:$ 孔食部分の真 の電流密度 $K_{b}:$ 定数

(6)式は $I_{w}$ を一定値とすれば， $K_{b}$ 定数， $I_{k}$ も一定と みなされるから， $\alpha$ に関する定数係数線形微分方程式 といえる。このため, $K_{b}\left(I_{w}-I_{k}\right)=0$ としたときの解 $\alpha_{t}$ と特解 $\alpha_{s}$ との和とおくことができる。

$\alpha_{t}: K_{b}\left(I_{w}-I_{k}\right)=0$ としたときの $\alpha_{t}$ は次の式を満足 する。

$$
\frac{d \alpha_{t}}{d t}+K_{b} I_{w} \alpha_{t}=0
$$

変数分離をすると

$$
\frac{d \alpha_{t}}{\alpha_{t}}=-K_{b} I_{w} d t
$$

これを積分すると，

$$
\ln \alpha_{t}=-K_{b} I_{w} t+A \quad(A: \text { 積分定数 }) \cdots \cdots \cdot(7)
$$

(7)式は次のように書き直せるから，

$$
\alpha_{t}=\operatorname{Mexp}^{-K_{b} I_{w} t}
$$

$M$ は $A$ (積分定数) の対数であるが，積分定数は任 意の值でよいから，これを改めて積分定数とする。 
Vol. 22, No.6，1971 シュウ酸および硝酸溶液中のアルミニウムの定電位における電流一時間曲線について

$\alpha_{s}^{* 1}: \alpha_{s}$ は(6) 式を満足する特別な解の意味で, 通常,

$$
\alpha_{s}=\frac{K_{b}\left(I_{w}-I_{\kappa}\right)}{K_{b} I_{w}}=\frac{I_{w}-I_{k}}{I_{w}}
$$

$$
\left(\frac{d o s}{d t}=0 \text { として } \alpha \text { をだす }\right)
$$

$$
\left(\begin{array}{l}
\frac{d\left(\frac{I_{w}-I_{k}}{I_{w}}\right)}{d t \searrow_{O}}+\frac{K_{b} I_{w}\left(I_{w}-I_{k}\right)}{I_{w}}=K_{b}\left(I_{w}-I_{k}\right) \\
\therefore K_{b}\left(I_{w}-I_{k}\right)=K_{b}\left(I_{w}-I_{k}\right) \\
\alpha_{s} \text { は }(6) \text { 式を満足する }
\end{array}\right)
$$

\section{と置けばよい。}

以上から (6) 式の一般解は, 次のようになる。

$a=a_{s}+\alpha_{t}=\frac{\left(I_{w}-I_{k}\right)}{I_{w}}+M e^{-K_{b} I_{w} t}$ (10)

(10)式の積分定数 $M$ 注初期条件から決定できる。いま 電極に皮膜が生成開始の瞬間の $t=0$ を考えると, この ときの $a$ は 0 と考えられるから，

$$
t=0 \quad \alpha=0
$$

(11)を(10) 式に代入すると

$$
M=-\frac{\left(I_{w}-I_{k}\right)}{I_{w}}
$$

となり，積分定数が決定される。したがって一般解は

$$
a=\frac{\left(I_{w}-I_{k}\right)}{I_{w}}\left(1-e^{-K_{b} I_{w} t}\right)
$$

(4) 式を(13) 式に代入すると，

$$
\begin{aligned}
& \frac{I_{w}-I_{g}}{I_{w}}=\frac{I_{w}-I_{k}}{I_{w}}\left(1-e^{-K_{b} I_{w} t}\right) \\
& I_{w}-I_{g}=I_{w}-I_{k}-\left(I_{w}-I_{k}\right)_{\mathrm{e}}-K_{b} I_{w} t \\
& \therefore I_{g}=I_{k}+\left(I_{w}-I_{k}\right) e^{-K_{b} I_{w} t}
\end{aligned}
$$

すなわち電流 $\left(I_{g}\right)$ は時間 $(t)$ の経過とともに, 指数 関数的に隇少してゆくことがわかる。

上記した第 1 図は，SCE基準で $2 \mathrm{Vからー0.3Vにア}$ ルミニウムの電位を一定に規制したときの $\log I$ と $\log T$ との関係を, プロットしたものである。

なお第 1 図における横軸の定数 Ks を58.72にした のは, 後報 3 ) で報告する硫酸溶液中のアルミニウムの設 定電位を OV にしたとき，求められた電流一時間曲線 をできるだけ満足させるような式を，電子計算機ではじ きだしたときに得られた数值である。具体的に得られた 数值と電算機によって求めた数値は, 必らずしも実験值 と完全に一致しているわけではなく，まだまだ問題点が 残る。

これらの事がらからわかることは，2 Vでは電解開始

$a *$ *1 の物理的な意味は定常状態の $a$ のことで，ここ では長時間電解が継続されると全部絶縁皮膜でおおわれ るので, $\nleftarrow \rightarrow 1$ となるものと考えられる。すなわら $I_{k} \rightarrow$ 0 （皮膜は，溶解しなくなる）となり(9) 式は 1 とな る。
後 $6 \mathrm{~s}$ 間は, アルミニウムの表面にイオン電導性皮膜の 生成反応が起こっていることを示す（2 Vは理論酸素発 生電位より貴の電位領域)。

それから第 1 図と第 2 図からも明りょらなように， 6 $\mathbf{s}$ 以後のアルミニウム電極は，イオン電導によって生成 した酸化皮膜が絶縁性皮膜まで変化しないものと考えら れる。現象的には $I_{K}>I$ となろう。電解時間が $4 \mathrm{~min}$ 経 過後には再度電流の減少が起こり, 千密な酸化皮膜の形 成を示唆する。

$1 \mathrm{~V}$ (酸素発生の境界電位) のときは，6 s のところ で傾斜のややゆるやかな直線となる。打とらくイオン電 導性皮膜と, 絶縁性皮膜からなる複雑な皮膜から成りた っているものと思われる。

$6 \mathrm{~s}$ 後の皮膜抵抗に, Ohm の法則が適用されると仮 定すると， $1.2 \times 10^{3} \Omega / \mathrm{cm}^{2}$, 絶縁皮膜が支配的と思われ る $30 \mathrm{~s}$ 後で約 $2.2 \times 10^{3} \Omega / \mathrm{cm}^{2}$ である。ただし表面の粗度 係数を 1 と仮定した。

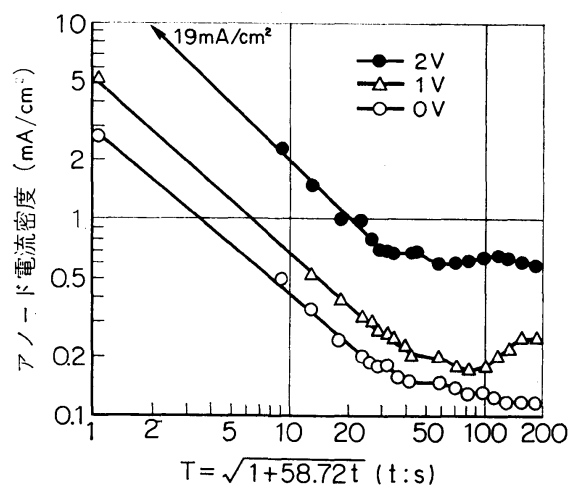

第 3 図定電位条件下でのシュウ酸溶液中の A1 P3 ( 2 S ) のアノード電流と時 間の各対数との関係

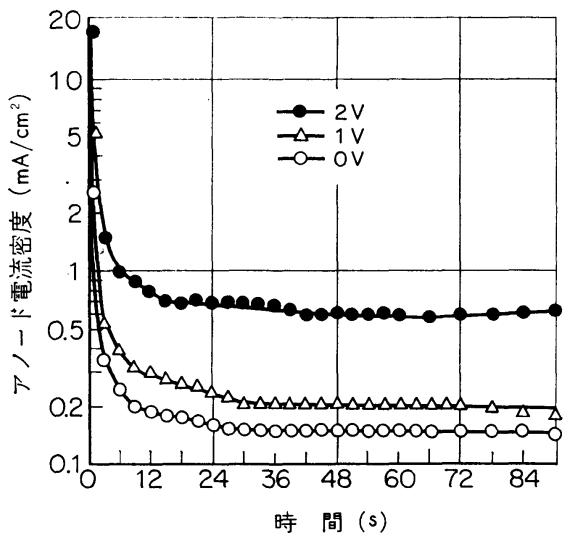

第 4 図定電位条件下でのシュウ酸溶液中の A1 P3（2S）のアノード電流の対 数と時間の関係 


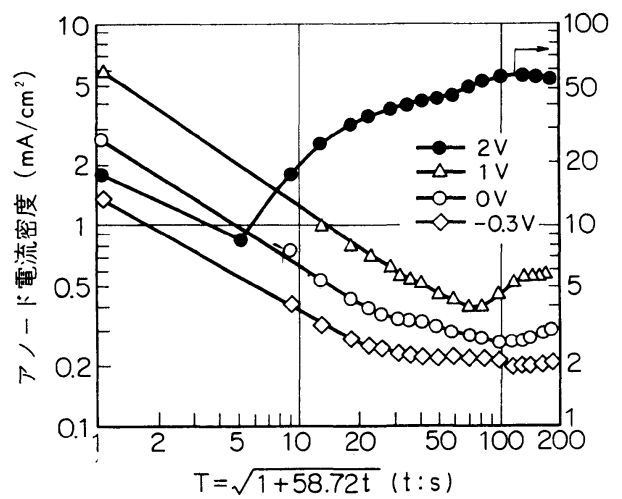

第 5 図定電位条件下での硝酸溶液中のアルミ ニウムのアノード電流と時間の各対数 との関係

$0.7 \sim-0.3 \mathrm{~V}$ (酸素発生電位より卑の電位領域) のと きには，各曲線ともほとんど類似の曲線を示すことか ら, 同質の電気化学的過程を示す。すなわち電解初期に はイオン電導性皮膜が, やがてそれらは絶縁性皮膜とな り, 電極界面では外部電流 $\mathrm{I}$ は $\mathrm{I} \approx \mathrm{I}_{\mathrm{K}}$ となって, 平衡状 態を持続しているものと推考される。A1P3（2S）の電 位を $2 \mathrm{~V}, 1 \mathrm{~V}$ と0 Vの各電位に一定に設定した場合の 実験結果を，第 3 図と第 4 図に示す。

これらの実験結果は，高純度アルミニウムの場合とほ とんど同じであることがわかる。換言すれば，高純度ア ルミニウムの表面状態も, A1 P3（2s）の表面も同じよ らな過程を経て変化しているものと思われる。

\section{3-2 硝酸溶液中のアルミニウムの電流一時間曲線に ついて}

高純度アルミニウム電極の電位を, $2 \mathrm{~V}, 1 \mathrm{~V}, 0 \mathrm{~V}$ とー0.3V の一定に設定した場合の実験結果の一例を,

\section{第 5 図と第 6 図に示す。}

$2 \mathrm{~V}$ に電位を設定したときには，電解時間が $1 \mathrm{~s}$ 後か らアノード電流は急激に増加する。 $40 \mathrm{~s}$ 前後から電流は やや一定値を示すが, 数 $\mathrm{mA}$ の微小電流の変化が常に生 起している。アルミニウムの表面には孔食が発生してい る。電解液中の微量 $\mathrm{Cu}^{2+}$ イオンが孔食の発生原因にな るとの報告4) もあるので, 電解液中の微量 $\mathrm{Cu}^{2+}$ イオン の分析を原子吸光分光光度計で目下検討中である。

$1 \mathrm{~V}$ の場合には第 5 図からわかるように, 電解後 $90 \mathrm{~s}$ まで $\log \mathrm{I}$ と $\log \mathrm{T}$ との間に直線関係が成立するので, イオン電導性皮膜が生成する。この皮膜も時間の経過と ともに, やがてアノード電流が増加するから，皮膜の溶 解が起こっているものと思われる。皮膜の溶解機構につ いての詳細は，この実験結果からだけではわからない。

$0 \mathrm{~V}$ と - 0.3V の場合は, ほとんど同じタイプの曲線 になる。これを解析すると次のようになる。電解後 $15 \mathrm{~s}$

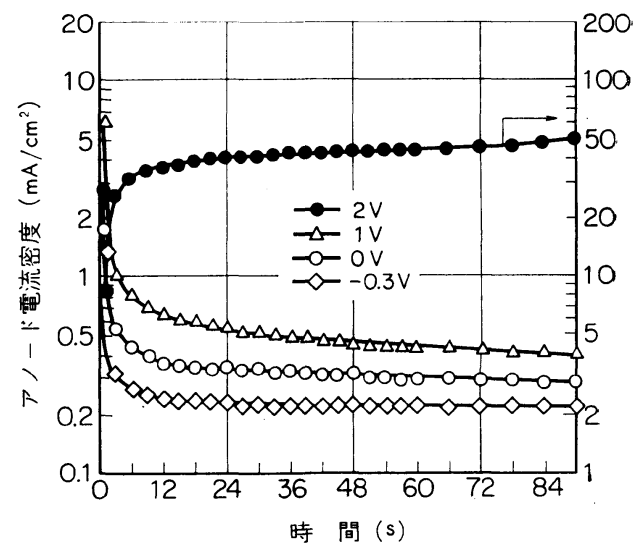

第 6 図定電位条件下での硝酸溶液中のアル ミニウムのアノード電流の対数と時 間の関係

間はイオン電導性皮膜の生成，その後はイオン電導が困 難な絶縁皮膜の生成反応が進行するであろう。

A 1 P 3 電極の電位を $2 \mathrm{~V}, 1 \mathrm{~V}$ と $0 \mathrm{~V}$ の一定に設定 した場合の実験結果の例を，第 7 図と第 8 図に示す。

2 Vに電位を一定にしたときには，高純度アルミニウ 么電極とほとんど同じ挙動を示す。すなわち電解後 0.3 . sからアノード電流は急激に増加する。40 s から電流は やや一定值を示すが, 数 $\mathrm{mA}$ の微小電流の変化が生じる ことも，孔食が発生することも，高純度アルミニウム電 極と同じである。沶そらく酸化皮膜の久陥部から，電流 が流れているのであろら。

1 Vに電位を一定にしたときは，0〜30s 間でイオン 電導性皮膜を生成することは, 高純度アルミニウムの場 合と同じである。このことは第 8 図の実験結果ともよく 一致する。やがてアノード電流の経時変化が一定となる 領域に入る。このときは前述した $\mathrm{I}_{\mathrm{K}} \approx \mathrm{I}$ となって，皮膜 が溶解しない状態になる。さらに時間が経過すると，ア ノード電流が増大するから，換言すれば $\mathrm{I}>\mathrm{I}_{\mathrm{K}}$ となって 皮膜が溶解するようになる。

OVV電位を一定にしたときは，0〜 $6 \mathrm{~s}$ 間はイオン電 導性皮膜の生成が，それ以後は電流の増加から，わずか ではあるが, 生成酸化皮膜の溶解反応が起こっていると 考えられる。

いずれにしても，硝酸溶液中では，絶縁皮膜のような 千密な酸化皮膜が生成しにくいものと思われる。

\section{4. 結 論}

（1） i ）シュウ酸溶液中で，設定電位を 2 Vに保持した ときには，0〜 $6 \mathrm{~s}$ 間は傾斜の一定した直線が生じ，こ れらはイオン電導による酸化皮膜の生成を意味する。6 $\mathrm{s}$ 以後のアルミニウム電極は絶縁性皮膜まで変化しな 


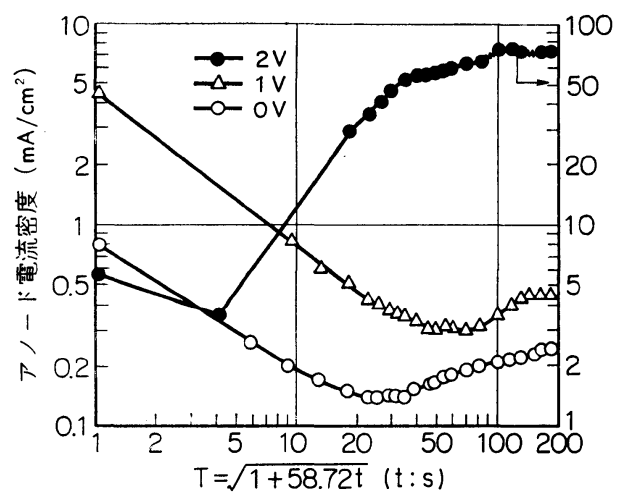

第 7 図定電位条件下での硝酸溶液中の A1P3 (2S)のアノード電流と時間の各対数 との関係

い。 $4 \mathrm{~min}$ 経過後には, アノード電流が減少してふたた びチ密な酸化皮膜を生成する。

ii ）設定電位が $1 \mathrm{~V}$ のときは, 電解時間が $6 \mathrm{~s}$ のと ころで, 傾斜の異なる 2 直線が生じる。生成皮膜はイオ ン電導性皮膜と絶縁性皮膜からなる複雑な皮膜であろ 5。

iii）設定電位を $0.7 \sim-0.3 \mathrm{~V}$ のときには，各曲線と も似た曲線を示す。すなわち電解初期にはイオン電導性 皮膜が，やがて絶縁性皮膜となる。

iv） A1 P3 の場合には, 高純度アルミニウムのとき と類似の曲線を示すから，同じ性質の電気化学的過程を 示すものと考えられる。

（2）ｉ）硝酸溶液中で，設定電位を 2 Vに保持したとき には, 電解時間が $1 \mathrm{~s}$ 後から電流は急速に増加する。

ii）設定電位を $1 \mathrm{~V} に$ 保持したときには，0～90 $\mathrm{s}$ 間 は $\log \mathrm{I}$ と $\log \mathrm{T}$ は直線関係が成立するから，イオン 電導によって皮膜が生成する。電解時間が経過すると電 流が増加するから, 皮膜の溶解が起こる。

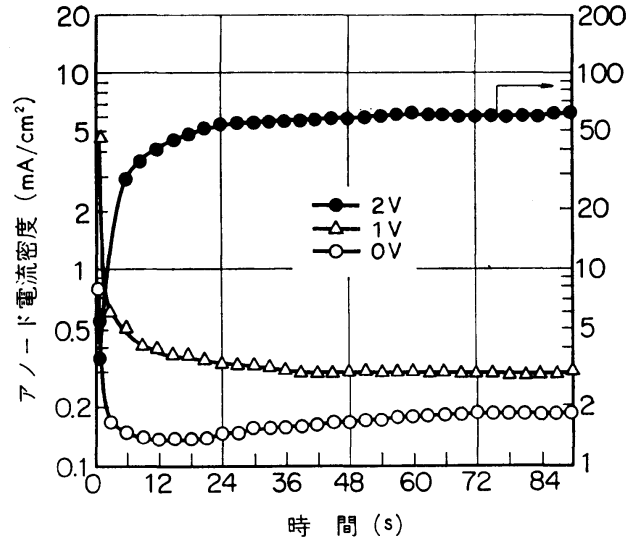

第 8 图定電位条件下での硝酸溶液中の A1 P3(2S) のアノード電流の対数と時 間の関係

iii）設定電位を 0〜ー0.3V に保持したときには，同 じタイプの曲線が得られる。これは (1) の iii）の実験 結果とはとんど同じである。

iv）A1 P3 の場合は, (2) の i ) と ii）の実験結果 と同じ電流一時間曲線を示すから，皮膜生成の電気化学 過程も同じであろう。

終わりにご支援くださった東北大学工学部外島 忍， 岡部泰二郎両教授ならびに電子計算機についていろいろ とご協力くださった当所の森 修身技師に厚く感謝致し ます。

(1970-12-23 受理)

\section{文献}

1）加藤正義：アルミニウムの腐食, 溶解機構とその電 池への応用 (学位論文)

2) U.F. Franck: Halbleiter probleme (II) p. 214 (1955)

3) 佐藤栄一：本誌に投稿中

4) H.H. Uhlig：防蝕技術，19，171（1970）

\section{アルミニウム表面処理内外特許総臨 頒布}

本協会アルミニウム表面処理研究会編集の『アルミニウム表面処理内外特許総覧』が発行され, 残部を希望者に頒 布しております。ご希望の向は下記によりお申込み下さい。

1. 内 容 大正 9 年より現在に至る, 関係内外特許約 600 件を集録

2. 体 裁 B 5 版, 32ページ, タイプオフセット印刷

3. 頒 価 1 部 1,000 円 (送料込み)

4. 申込方法 代金を添光，送付先を明記し，本協会「A1特許総覧係」宛お申込み下さい。 